\title{
Exploitation of Antarctic Iced Freshwater: A Call To Unfreeze Legal Discourse
}

Keywords:

Ana Costov ${ }^{*} \&$ Jessica Appelmann ${ }^{* *}$

DOI: $10.21827 /$ GroJIL.9.1.60-77

ANTARCTIC TREATY SYSTEM; ICED FRESHWATER RESOURCES; ICEBERG HARVESTING; MADRID PROTOCOL; ENVIRONMENTAL IMPACT ASSESSMENT

\begin{abstract}
While discussed within the Antarctic Treaty System during the 1970s-1980s, the idea of iceberg harvesting was laid on ice due to the lack of adequate technologies and scientific knowledge on the potential environmental implications. However, the State Parties to the ATS envisioned the possibility of reopening the legal discourse. For that purpose, iced freshwater resources exploitation was excluded from the scope of the Madrid Protocol containing a ban on all mineral mining activities within the scope ratione loci of the ATS. However, during the negotiations, it was agreed that if the prospect of iceberg harvesting was ever to be realised, the environmental protection provisions under the Madrid Protocol should apply. The present paper provides an analysis of whether the potential exploitation of iced freshwater resources proves realistic within the existing legal framework under the Antarctic Treaty System and the United Nations Convention on the Law of the Sea and discusses which rules States would need to adhere to when engaging in such activities. It arrives at the conclusion that, as to now, there is no prohibition of iceberg harvesting for freshwater use under international law. Nevertheless, both within the scope of the ATS and in the high seas, environmental regulations restrict the implementation of the activity and, therefore, require comprehensive environmental impact assessments to be conducted before the commencement of the activity. Furthermore, as ownership allocation of icebergs is not regulated under the relevant treaties, the present paper examines two legal regimes that may potentially govern iceberg acquisition in the high seas, namely, res nullius and res communis. Finally, as private efforts have become more far-reaching in the recent decades, an overview of the current state of practice is presented, highlighting the observed advantages and potential drawbacks. Conclusively, the present paper advocates for the reopening of the legal discourse on the subject matter before the commencement of exploitation activities so as to ensure that the fragile Antarctic environment is protected and preserved for the benefit of all humankind in accordance with the object and purpose of the ATS.
\end{abstract}

\footnotetext{
* Ana Costov holds an LLM (cum laude) in Energy \& Climate Law from the University of Groningen. anacostov98@gmail.com.

** Jessica Appelmann holds an LLM in Public International Law from the University of Groningen and is an LLM candidate in Energy \& Climate Law at the same university. jessappelmann@gmail.com.
} 


\section{Introduction: Can Antarctic icebergs solve the problem of freshwater scarcity?}

Today, the problem of freshwater scarcity and, particularly, the lack of drinking water affects every continent and is increasingly exacerbated by climate change. ${ }^{1}$ According to the United Nations Sustainable Development Goal 6 Synthesis Report on Water and Sanitation, about 2.1 billion people lack safely managed drinking water, ${ }^{2}$ while 4 billion 'experience severe water scarcity during at least one month of the year'. ${ }^{3}$ On the other hand, the human right to water, derived from articles 11 and 12 of the International Covenant on Economic, Social and Cultural Rights (ratified by 171 States), 'entitles everyone to sufficient, safe, acceptable, physically accessible and affordable water for personal and domestic uses' ${ }^{5}$ Thus, the rapidly deteriorating freshwater scarcity is a serious and multidimensional issue that requires prompt action for long-term solutions.

One ambitious solution that has been frequently proposed in the context of water crises throughout the world presupposes using icebergs as the source for freshwater by towing them to the shore. The idea of iceberg harvesting is not a novel one. Whereas there are records of glacier ice being towed for drinking water as early as $1852-53,{ }^{6}$ the debate surrounding the achievability of towing of icebergs for drinking water gained traction among scientists in the 1970s. It is yet to proceed beyond the theorising phase; however, with modern technological progress, iceberg harvesting may become a viable solution in the near future. ${ }^{7}$ The prospect of exploiting icebergs in order to satisfy rising freshwater demand (estimated to exceed supply by $40 \%$ in 2030$)^{8}$ means that all eyes will turn to Antarctica, as its icebergs contain enough freshwater to satisfy the annual needs of 5 billion people. ${ }^{9}$ Antarctic icebergs have a tabular shape, rendering them easier to tow than Arctic icebergs, for example, which are generally considered 'unstable' and thus unsuitable for transport. ${ }^{10}$ Interestingly, several 'mega-icebergs' have recently been spotted calving off and drifting away from the Antarctic shore, with the

1 UN Water, 'Water Scarcity' (UN Water) <www.unwater.org/water-facts/scarcity/> accessed 26 November 2020.

2 UN Water, 'SDG 6 Synthesis Report 2018 on Water and Sanitation' (UN Water, 2018) 13.

3 UN Water, 'UN World Water Development Report: Leaving No One Behind' (UN Water, 2019) 14.

4 See Office of the High Commissioner for Human Rights, 'Status of Ratification Interactive Dashboard: International Covenant on Economic, Social and Cultural Rights' (OHCHR, 29 September 2020) $<$ https://indicators.ohchr.org/> accessed 27 November 2020.

5 CESCR 'General Comment No 15 (2002): The right to water (arts 11 and 12 of the International Covenant on Economic, Social and Cultural Rights' (20 January 2003) UN Doc E/C.12/2002/11, paras 2,3.

6 Wilford F Weeks and William J Campbell, 'Icebergs as a Fresh-Water Source: An Appraisal' (1973) 12(65) Journal of Glaciology 207, 209.

7 See Bryan S Geon, 'A Right to Ice?: The application of international and national water laws to the acquisition of iceberg rights' (1997) 19(1) Michigan Journal of International Law 277, 279-81.

8 C Winter, 'Towing an Iceberg: One Captain's Plan to Bring Drinking Water to 4 Million People' Bloomberg Green (New York, 6 June 2019) <bloomberg.com/news/features/2019-06-06/towing-an-iceberg-onecaptain-s-plan-to-bring-drinking-water-to-4-million-people> accessed 26 November 2020.

9 Cory J Lewis, 'Iceberg Harvesting: Suggesting a Federal Regulatory Regime for a New Freshwater Resource' (2015) 42 IELR 439, 443.

10 Tim Smedley, 'The Outrageous Plan to Haul Icebergs to Africa' BBC (London, 21 September 2018) $<$ www.bbc.com/future/article/20180918-the-outrageous-plan-to-haul-icebergs-to-africa $>$ accessed 26 November 2020. 
world's largest iceberg-A-76 — breaking off Antarctica's Renn Ice Shelf at the end of May. ${ }^{11}$ Scientists raised concerns over the potential implications that the drifting icebergs could have on the marine ecosystems they would be passing through. ${ }^{12}$ Such concerns and the attention generated by the recently increasing calving of 'mega-icebergs', as well as the pressing impending freshwater crisis, illustrate the necessity of reviving the legal discussion on Antarctic iceberg harvesting, particularly as the majority of the literature on this subject dates back to 20-30 years ago.

Therefore, the present paper aims at providing a comprehensive analysis of the legal regimes currently governing the possibility of harvesting iced freshwater resources (IFR) in the South Polar Region. It points to the controversial aspects and legal gaps connected to the harvesting of Antarctic icebergs and explores possibilities to fill these gaps. Finally, we argue that given the rapid technological developments and the aggravation of the global water scarcity situation, States need to readdress the question of IFR exploitation with a view to ensuring the highest degree of protection of the Antarctic environment.

\section{Overview of the Legal Framework: The Antarctic Treaty System} A. The Antarctic Treaty

In the first half of the 20th century, heated discussion ensued over an icy continent, with numerous States advancing rivalling interests in Antarctica. For Australia, New Zealand, France, Norway, the United Kingdom, Chile, and Argentina, these interests consisted of territorial sovereignty claims. ${ }^{13}$ Whereas the claims of the States from the South American and Oceanian regions are related to their geographical proximity to Antarctica, Norway had interests in whaling and sealing, and the other two European States wanted to protect their explorative and scientific endeavours. ${ }^{14}$ The main concern of the USA and USSR, on the other hand, was the non-recognition of the aforementioned sovereignty claims - whilst nevertheless desiring to reserve their own rights to make sovereignty claims in the future. ${ }^{15}$ In spite of previously failed negotiation attempts, the International Geophysical Year (1957-58) showed the aforementioned States and three others involved in scientific endeavours - Belgium, South Africa, and Japan - that fruitful international cooperation in science is possible even in times of political disagreement. ${ }^{16}$ Thus, with the aim of continuing mutually beneficial cooperative efforts in science and, importantly, maintaining peace, twelve States came together to prevent an escalation of their rivalling interests in the Antarctic region and concluded the Antarctic Treaty on 1 December $1959 .{ }^{17}$ This undertaking was, and remains, successful as a result of a crucial provision: a moratorium on State Parties' sovereignty claims. This 'freeze' is four-fold,

11 Jonathan Amos, 'Radar images capture new Antarctic mega-iceberg' BBC News (London, 1 March 2021) $<$ https://www.bbc.com/news/science-environment-56241503> accessed 14 March 2021. See also 'Huge Antarctic Iceberg headed towards South Georgia breaks in two' The Guardian (London, 18 December 2020) <https://www.theguardian.com/world/2020/dec/18/massive> accessed 14 March 2021; Claire Fahy, 'Iceberg Splits From Antarctica, Becoming World's Largest' New York Times (New York, 22 May 2021) <www.nytimes.com/2021/05/20/world/iceberg-antarctica-ronne-a 76.html> accessed 3 June 2021.

12 Amos (n 11).

13 Rolph Trolle-Anderson, 'The Antarctic scene: legal and political facts' in The Antarctic Treaty Regime (CUP 1987) 57.

14 Gillian D Triggs, 'Introduction' The Antarctic Treaty Regime (CUP 1987) 52.

15 Trolle-Anderson (n 13) 58.

16 ibid 58-59.

17 ibid 59. 
in that it provides that nothing under the Antarctic Treaty shall be interpreted as (1) a renunciation or diminution of any previous claims or bases for claims (based on activities undertaken in the region) of a State Party, (2) recognition or non-recognition of any other State's claim or basis of claim, (3) 'a basis for asserting, supporting or denying a claim', and (4) no new claims or enlargement of existing claims may be made for the duration of the treaty. ${ }^{18}$

Today, there are 29 consultative members and 25 non-consultative members of the Antarctic Treaty. ${ }^{19}$ Whereas consultative members have the right to vote during meetings of the State Parties, non-consultative members may only attend without a right to vote. While the Antarctic Treaty is generally open for accession to any United Nations Member State or any other State invited with the consent of all consultative members, ${ }^{20}$ a State may only become a consultative member if it has demonstrated a significant research activity in the Antarctic. ${ }^{21}$ In the last six decades, the State Parties to the Antarctic Treaty have allowed the fundamental regime to evolve into the comprehensive Antarctic Treaty System (ATS), which additionally entails the 1972 Antarctic Seals Convention, ${ }^{22}$ the 1980 Convention on the conservation of Antarctic marine living resources (CCAMLR), ${ }^{23}$ the 1991 Madrid Protocol on Environmental Protection in the Antarctic Treaty, ${ }^{24}$ and theoretically - although not in force - the 1988 Convention on the Regulation of Antarctic Mineral Resource Activities (CRAMRA). ${ }^{25}$ This regime is refined and kept up to date via recommendations and measures adopted by the consultative members and several established treaty bodies. ${ }^{26}$ Additionally, other treaties, such as the United Nations Convention on the Law of the Sea (UNCLOS) ${ }^{27}$ and the Protocol of 1978 relating to the International Convention for the Prevention of Pollution from Ships (MARPOL), ${ }^{28}$ for example, may apply to the region, defined in the Antarctic Treaty as the area south of $60^{\circ}$ South Latitude, including all ice shelves. ${ }^{29}$ This is the case particularly with regard to the high seas in the area, as article VI Antarctic Treaty provides that nothing therein 'shall prejudice or in any way affect the rights, or the exercise of the rights, of any State under international law with regard to the high seas within that area'. ${ }^{30}$ This reference to the high seas specifically, rather than other notions of the law of the sea, is relevant

18 The Antarctic Treaty (concluded 1 December 1959, entered into force 23 June 1961) 402 UNTS 71 (Antarctic Treaty) art IV.

19 Secretariat of the Antarctic Treaty, 'Parties' (Antarctic Treaty, 2021) <https://www.ats.aq/devAS/Parties?lang=e> accessed 14 March 2021.

20 Antarctic Treaty (n 20) art XIII.

21 ibid art IX(2).

22 Convention for the Conservation of Antarctic Seals (concluded 1 June 1972, entered into force 11 March 1978) 1080 UNTS 175.

23 Convention on the Conservation of Antarctic Marine Living Resources (concluded 20 May 1980, entered into force 7 April 1982) 1329 UNTS 47 (CCAMLR).

24 Protocol on Environmental Protection in the Antarctic Treaty (concluded 4 October 1991, entered into force 14 January 1998) 2941 UNTS 1 (Madrid Protocol).

25 Convention on the Regulation of Antarctic Mineral Resource Activities (concluded 2 June 1988) <https://documents.ats.aq/recatt/att311_e.pdf> (CRAMRA).

26 See Madrid Protocol (n 24) art 1(e).

27 United Nations Convention on the Law of the Sea (concluded 10 December 1982, entered into force 16 November 1994) 1833 UNTS 3 (UNCLOS).

28 Protocol of 1978 relating to the International Convention for the prevention of pollution from ships, 1973 (concluded 17 February 1978, entered into force 19 October 1983) 1341 UNTS 3 (MARPOL).

29 Antarctic Treaty (n 18) art VI.

30 ibid art 4. 
as a result of the moratorium on sovereignty claims, which precludes the existence of territorial seas or exclusive economic zones around Antarctica. ${ }^{31}$ Thus, all waters around the Antarctic are considered high seas. ${ }^{32}$ When the Antarctic Treaty was concluded, UNCLOS had not yet been adopted, meaning that the concept of exclusive economic zones did not exist yet. However, should the sovereignty claims ever be unfrozen, the respective States could and would most likely claim both territorial seas and exclusive economic zones.

\section{B. The 1988 Convention on the Regulation of Antarctic Mineral Resource Activities}

Whereas the Antarctic Treaty codified State Parties' agreement to 'freeze' claims of national sovereignty and designated Antarctica as a region intended for peace and international scientific cooperation, ${ }^{33}$ it remained silent on the topic of resource exploration and exploitation. This lack of regulatory provisions is largely owed to the fact that in 1959 - at the time of the conclusion of the Antarctic Treaty - the prospect of exploitation activities on the continent seemed unfeasible due to its harsh climatic conditions and the absence of the required technological equipment. Moreover, since the exploitation of natural resources is closely linked to State sovereignty, this subject was avoided due to its high political sensitivity. ${ }^{34}$ However, the desire to exploit Antarctica's mineral wealth was nevertheless present, reinforced by the 1973 oil crisis. ${ }^{35}$

In 1988, following multiple rounds of negotiations, CRAMRA was concluded. Laying down an extensive regime of mineral exploitation complemented by a system of strong environmental protection mechanisms, CRAMRA was the first attempt of State Parties to open up Antarctica to human activities beyond scientific research. Importantly, while hydrocarbons and other mineral resources would fall under the scope ratione materiae of CRAMRA, the treaty's scope excluded the exploitation of IFR. ${ }^{36}$ When negotiating CRAMRA, State Parties explicitly stated that 'mineral resources, as defined in Article 1(6) of the Convention, do not include ice'. ${ }^{37}$ The possibility of the 'harvesting of ice, including icebergs' was acknowledged, although concerns were raised as to the adverse impacts of such activities 'on the Antarctic environment'. ${ }^{38}$ However, following a passionate lobbying campaign by environmental NGOs and the refusal of Australia and France to ratify the treaty, CRAMRA never entered into force. Apart from political concerns over the mining regime

31 The notions of territorial seas and exclusive economic zones are dependent on the existence of a coastal State. See UNCLOS (n 27) arts 2 and 55 respectively.

32 See UNCLOS (n 27) art 86; See also JE Viñuales, 'Iced Freshwater Resources: A Legal Exploration' (2009) 20(1) Yearbook of International Environmental Law 188, 191.

33 UNCLOS (n 27) arts 1, 3.

34 Emil A Zuccaro, 'Iceberg Appropriation and the Antarctic's Gordian Knot' (1979) 9(2) California Western international Law Journal 405, 409; For an extensive discussion of the difficulties faced by States during the negotiations of the Antarctic Treaty, see John Hanessian, 'The Antarctic Treaty 1959' (1960) 9(3) International and Comparative Law Quarterly 436.

35 Doaa Abdel-Motaal, Antarctica: The Battle for the Seventh Continent (Praeger Press 2016) 85.

36 CRAMRA (n 25) art 1(6).

37 ATCM, 'Final Act of the Fourth Special Antarctic Treaty Consultative Meeting on Antarctic Resources' (1988), para 8.

38 ibid. 
potentially prejudicing sovereignty claims, ${ }^{39}$ the lack of an authorisation requirement for minerals prospecting was deemed to pose a threat to the fragile Antarctic ecosystem. ${ }^{40}$

\section{The 1998 Madrid Protocol}

Consequently, with the aim of creating an environmental regime more stringent than CRAMRA, ${ }^{41}$ the Madrid Protocol was negotiated and entered into force in $1998 .{ }^{42}$ Designating the continent as a 'natural reserve', ${ }^{43}$ the core of this instrument lies in its article 7, which prohibits 'any activity relating to mineral resources, other than scientific research' ${ }^{44}$ The protocol underlines and supports the general purpose of the ATS, which devotes the Antarctic to 'peace and science', with activities limited to those 'in the interest of mankind as a whole'. ${ }^{45}$ To this effect, it lays down that priority is to be accorded to scientific research and to Antarctica's value for this purpose. ${ }^{46}$

In order to limit adverse impacts on the environment, it sets out the following requirements, applicable 'in the planning and conduct of all activities' within the ATS' territorial scope so as to avoid

(i) adverse effects on climate or weather patterns; (ii) significant adverse effects on air or water quality; (iii) significant changes in the atmospheric, terrestrial (including aquatic), glacial or marine environments; (iv) detrimental changes in the distribution, abundance or productivity of species or populations of species of fauna and flora; (v) further jeopardy to endangered or threatened species or populations of such species; or (vi) degradation of, or substantial risk to, areas of biological, scientific, historic, aesthetic or wilderness significance. ${ }^{47}$

Where 'impacts upon the Antarctic environment or dependent or associated ecosystems' contrary to these 'principles' cannot be avoided with certainty, any expeditions to and within Antarctica shall be 'modified, suspended or cancelled' ${ }^{48}$ Although the choice of the word 'principles' appears to be lacking stringency - 'requirements', 'rules' or 'standards' might have offered a clearer obligation - the Madrid Protocol sets out a strict precautionary approach. Crucially, the Protocol details all elements of information which environmental impact assessments (EIAs) need to include to ensure compliance with these conditions. ${ }^{49}$ The procedures and requirements concerning such EIAs are laid down in Annex I to the Madrid Protocol. Annex I differentiates between activities having less than a minor or transitory impact, those with a minor or transitory impact, and those having more than a minor or

Abdel-Motaal (n 35) 85.

40 CRAMRA (n 25) art 10; Abdel-Motaal (n 35) 102, 104.

41 ibid; Samuel Kwaw Nyameke Blay, 'New Trends in the Protection of the Antarctic Environment: 1991 Madrid Protocol' (1992) 86 American Journal of International Law 377, 399; The Madrid Protocol is supplemented by six annexes on EIA, Fauna and Flora, Waste Disposal, Marine Pollution, Protected Areas, and Liability.

42 Philippe Sands, Principles of International Environmental Law (CUP 2003) 716, 722.

43 Madrid Protocol (n 24) art 2.

44 ibid art 7.

45 ibid preamble, arts 2-5.

46 ibid art 3(3).

47 ibid art 3(1),(2)(a),(b).

48 ibid art 3(4)(b); ATS, art VII(5).

49 Madrid Protocol (n 24) art 3(2)(c). 
transitory impact. ${ }^{50}$ Activities with an impact that is less than minor or transitory, such as, for instance, annual or educational expeditions, must only undergo a Preliminary Assessment. ${ }^{51}$ With regard to this category, the evaluation process is usually left at the discretion of the national authorities responsible for overseeing Antarctic environmental affairs. ${ }^{52}$ Where an activity is determined to have a minor or transitory impact, such as touristic activities, an Initial Environmental Evaluation needs to be conducted. ${ }^{53}$ In cases where this assessment or another source indicate that the impact will exceed the threshold of minor or transitory, such as in cases of construction or drilling activities, a Comprehensive Environmental Evaluation must be conducted. ${ }^{54}$ Accordingly, activities with a minor or transitory impact may proceed being subjected to continued assessment, e.g. via monitoring. Activities with a more significant impact, conversely, are subject to rigorous scrutiny and decision-making processes by the Committee for Environmental Protection (Committee) and the Antarctic Treaty Consultative Meeting (ATCM) ${ }^{55}$

\section{Exploitation of Iced Freshwater Resources under the Antarctic Treaty System}

\section{A. Iced Freshwater Resources under ATS Measures}

When negotiating the Madrid Protocol, the Parties consciously chose to reserve the possibility of IFR exploitation within the ATS. In this context, Recommendation XV-21 was adopted, in which the representatives '[noted that] technological developments might one day make it possible to utilise icebergs detached from the continent for freshwater requirements, especially in coastal areas'. ${ }^{56}$ Importantly, the consultative Parties acknowledged that this could have negative impacts on the unique Antarctic environment and ecosystems if executed in an unregulated manner, especially if land-based installations were to be used for this purpose. ${ }^{57}$ Whereas the representatives emphasised the effectiveness of the ATS in promoting peace, scientific cooperation, and protecting the environment, they also highlighted the lack of sufficient information on the environmental and climatic impacts of the exploitation of floating icebergs. ${ }^{58}$ Thus, recognising that commercial exploitation should not be engaged in before the potential environmental impacts thereof would be appropriately examined ${ }^{59}$ the ATCM recommended to its governments that they 'exchange information on the feasibility

50 See Annex I to the Protocol on Environmental Protection the Antarctic Treaty (Annex I) arts 1-3.

51 ibid art 1(2). See also ATCM/SP, 'Annual list of Initial Environmental Evaluations (IEE) and Comprehensive Environmental Evaluations (CEE)' (2008) XXXI ATCM.

52 Sergey Tarasenko, 'Environmental impact assessment in Antarctica: application of the "minor or transitory impact" criterion' (PGCertAntaStud, University of Canterbury 2009).

53 Annex I (n 50) art 2(1). See also Ricardo Roura and Kees Bastmeijer, 'Environmental Impact Assessment in Antarctica' in Kees Bastmeijer and Timo Koivurova (eds), Theory and Practice of Transboundary Environmental Impact Assessment (Brill/Martinus Nijhoff Publishers 2008), 189.

54 ibid art 3. See also Alan D Hemmings and Lorne K Kriwoken, 'High level Antarctic EIA under the Madrid Protocol: state practice and the effectiveness of the Comprehensive Environmental Evaluation process' (2010) 10 Int Environ Agreements 187, 194-195.

55 ibid arts 2(2), 3.

56 ATCM, 'Recommendation XV-21' (1989) ATCM XV, preamble recital 2.

57 ibid preamble recitals 5,7 .

58 ibid preamble recitals $4,6,8$.

59 ibid preamble recital 9. 
of commercial exploitation of icebergs, relevant technologies and possible environmental impacts' ${ }^{60}$ However, it appears that the exploitation of Antarctic ice as a source of freshwater has not been discussed further since. ${ }^{61}$

Nevertheless, Recommendation XV-21, effective since $2004,{ }^{62}$ is of paramount importance with a view to interpreting the ATS concerning the possibility of exploiting IFR. Whereas it was up to each State to decide for itself how to implement recommendations under article IX Antarctic Treaty domestically, all but two Consultative Parties - Japan and France - considered them to be binding in themselves upon approval, while the latter two required domestic implementing measures for these instruments to become binding. ${ }^{63}$ In any case, recommendations under article IX of the Antarctic Treaty also represent a form of subsequent agreement of the Parties on the evolution of the ATS so as to serve as interpretative tools for the Antarctic Treaty and the Madrid Protocol in accordance with the customary rule of interpretation enshrined in article 31(3)(a) VCLT. ${ }^{64}$ Thus, having regard to Recommendation XV-21, as well as the Final Act of the Eleventh Antarctic Treaty Special Consultative Meeting (ATSCM), a fairly clear picture of the current legal situation under the ATS develops. The recommendation clearly points to the caveats concerning the harvesting of icebergs at the time and further indicates a potential framework and steps to be taken in this respect, outlining States' precautionary approach that is apparent from the desire to postpone any commercial exploitation until more information is available. ${ }^{65}$ In its Final Act, the Eleventh ATSCM explicitly pointed out that the prohibition on 'mineral resource activity' to be adopted in the Madrid Protocol did not apply to the harvesting of ice, which should, as understood by the Parties, be governed by the remainder of the Madrid Protocol once it became technologically possible. ${ }^{66}$ This appears to indicate the Parties' belief that the ATS, as it is now (with the Madrid Protocol in force), provides an adequate legal framework to govern the exploitation of icebergs. This apparent belief is reinforced by the reference to the ATS as 'the most appropriate framework for fostering international efforts to guarantee the protection of the environment' in Recommendation XV-21. ${ }^{67}$

\section{B. Iced Freshwater Resources under the Madrid Protocol}

It appears from the EIA database of the ATS and anecdotal evidence that, following the suspension of discussion on the topic, no (public) EIA concerning the exploitation of icebergs has been conducted either. ${ }^{68}$ Thus, one can merely speculate whether permission for IFR

60 ibid para 1.

61 No mention has been made of this issue in any documents in the ATS database since the XI ATSCM.

62 See Secretariat of the Antarctic Treaty, 'Recommendation XV-21 (ATCM XV - Paris, 1989)' (ATS, 2020) <www.ats.aq/devAS/Meetings/Measure/190> accessed 26 November 2020 and art IX(4) Antarctic Treaty. Christopher C Joyner, 'Recommended Measures Under the Antarctic Treaty: Hardening Compliance with Soft International Law' (1998) 19(2) Michigan Journal of International Law 401, 422-26.

64 See Antarctic Treaty (n 20) art IX(1),(4); Vienna Convention on the Law of Treaties (adopted on 22 May 1969, entered into force on 27 January 1980) 1155 UNTS 331 (VCLT), art 31.

65 cf Viñuales (n 32), 195.

66 ATSCM, 'Final Act of the Eleventh Antarctic Treaty Special Consultative Meeting' (1991) XI ATSCM, para 6.

67 Recommendation XV-21 (n 56) preamble recital 8.

68 See Secretariat of the Antarctic Treaty, 'EIA Database' (ATS, 2020)

<www.ats.aq/devAS/EP/EIAList?lang=e> accessed 26 November 2020; MH Birkhold, '\$166 Water Could Dictate International Iceberg Law' (The Atlantic, 31 October 2019) 
harvesting could be granted under the ATS. Without being particularly well-versed in climate science or marine biology, the present authors assume that such endeavours could likely cause 'adverse effects on climate and weather patterns'; 'significant adverse effects on air or water quality' (especially the latter); 'significant changes in terrestrial (including aquatic), glacial or marine environments'; or the degradation of, or substantial risk to, areas of biological, scientific, historic, aesthetic or wilderness significance' ${ }^{69}$ The applicable rules under the Madrid Protocol certainly seem to outrule the harvesting of IFR still attached to the Antarctic continent, since this would mean active, significant changes to the Antarctic environment, including potential degradation of the aforementioned areas of significance or even detriment to local fauna and flora. ${ }^{70}$ In any case, the Committee only ever considered 'icebergs detached from the continent' in its Recommendation XV-21. ${ }^{71}$ However, even the removal of icebergs floating at sea which one might consider to be of minor impact as they would melt regardless, could have significant environmental impacts, as their presence or removal will naturally affect water temperatures and salinity, i.e. water quality. ${ }^{72}$ In this respect, some experts have found that the development of krill, for example, 'a key organism in Antarctic ecosystems', is highly dependent on these factors. ${ }^{73}$ With a view to these potential effects, the impact of harvesting icebergs would certainly not be below the threshold of minor or transitory, meaning that at least an Initial Environmental Evaluation but most likely a Comprehensive Environmental Evaluation would be required under the Madrid Protocol. The persistent uncertainty surrounding the environmental impact of iceberg harvesting indicates the need to reopen the discussion on this matter within the ATS, both scientifically and legally, as initially recommended by the Committee over three decades ago.

\section{Iced Freshwater Resources under UNCLOS}

In light of the fact that icebergs do not simply remain in one place, another acute question is which rules would apply to icebergs that do not fall inside the scope ratione loci of the ATS, ${ }^{74}$ that is, if an iceberg which has drifted out of the Antarctic region is 'found' at sea. Without much doubt, States would be allowed to harvest icebergs that drift into their territorial sea or their exclusive economic zone, since States have sovereignty over the former, and UNCLOS provides for the exercise of sovereign rights for the purposes of exploiting non-living natural resources in the latter (subject to the limits of UNCLOS and other applicable provisions of international law). ${ }^{75}$ The issue becomes tainted with lack of clarity when one considers an iceberg drifting in the high seas. As under the ATS, the law of the sea does not entail any

<www.theatlantic.com/science/archive/2019/10/iceberg-water-and-race-exploit-arctic/601147/> accessed 26 November 2020.

69 Madrid Protocol (n 24) arts 3(2)(b)(i-iii, vi).

70 ibid art 3(2)(iii, iv, vi).

71 Recommendation XV-21 (n 56) preamble recital 2.

72 For studies assessing the environmental and climatic impact of drifting icebergs, see Julie Dinasquet and others, 'Mixing of water masses caused by a drifting iceberg affects bacterial activity, community composition and substrate utilization capability in the Southern Ocean' (2017) 19(6) Environmental Microbiology 2453; Mark J Hopwood and others, 'Highly variable iron content modulates iceberg-ocean fertilisation and potential carbon export' Nature Communications 10, 5261 (2019) <https://doi.org/10.1038/s41467-01913231-0>.

73 see Viñuales (n 32) 196.

74 ibid 197.

75 UNCLOS (n 27) arts 2 and 56(1)(a), (2) respectively; see also Geon (n 7), 283. 
prohibition of iceberg harvesting, but UNCLOS provides an array of environmental protection provisions to be taken into account when engaging in such activities. Like the Antarctic region, the high seas may only be used for peaceful purposes (and no sovereignty claims may be made either) ${ }^{76}$ Furthermore, States have a duty to take measures, and cooperate with other States in doing so, as may be necessary for the conservation of the living resources of the high seas. ${ }^{77}$ Although, this duty is normally read in the context of exploiting living resources, it could be pertinent to iceberg harvesting given the latter's potential effects on marine life (e.g. on krill) as mentioned in section III.B above. The relevance of this issue is reinforced by article 194(5) UNCLOS, which provides that the obligation to take measures in accordance with Part XII UNCLOS 'shall include those [measures] necessary to protect and preserve rare or fragile ecosystems' ${ }^{78}$ Part XII further lays down States' obligations with respect to specific forms of pollution potentially applicable to iceberg harvesting, including greenhouse gas emissions from iceberg transport, discussed in section V.C below. ${ }^{79}$ Thus, although UNCLOS does not contemplate iceberg harvesting, the existing framework provides a level of protection similar to that of the ATS. ${ }^{80}$

\section{Analysis: Communis Opinio and Controversial Matters}

The above sections illustrate that, in spite of the strong precautionary approach adopted by the ATCM in Recommendation XV-21, the current international legal framework does not per se prohibit the exploitation of Antarctic IFR, regardless of whether harvesting would take place within the geographical scope of the ATS or UNCLOS. On the contrary, a necessary legal lacuna has been left in the anticipation of iceberg harvesting becoming more plausible in light of technological progress and increasing scientific insight. Until now, protection of the Antarctic environment has remained the top priority, as State Parties suspended any IFRrelated activities until more information on its environmental impacts would be available. Therefore, no attempts to establish a clear legal regime governing IFR have been undertaken. In the absence of a specialised treaty, iceberg harvesting if ever engaged in, will be regulated by the Madrid Protocol within the geographical scope of the ATS and therefore subject to its environmental protection restrictions, including the duty to conduct EIAs. Its applicability begs the question of whether the Protocol offers sufficient protection from potential adverse environmental consequences of iceberg harvesting. While declared the 'most comprehensive and stringent regime of environmental protection' by some scholars, ${ }^{81}$ the Madrid Protocol has also been heavily criticised for having a weak implementation and enforcement system, thus creating but 'an illusion of strong environmental protection in Antarctica'. ${ }^{82}$ How effective its framework and enforcement could prove also depends on how entities would acquire icebergs.

Thus, a crucial question is under what type of appropriation regime harvesters would obtain an iceberg. While ATS consultative members envisioned IFR harvesting to be governed

\footnotetext{
ibid arts 88,89 .

ibid art 117 (et seq).

ibid arts 192, 194(5).

see ibid arts 194, 196, 211.

see UNCLOS (n 27) Parts VII and XII; Madrid Protocol (n 27) and its Annex I (n 50).

81 Sands (n 43) 722.

82 Abdel-Motaal (n 35) 245. For more extensive criticism of the Madrid Protocol see Abdel-Motaal and ibid 726.
} 
by the ATS, particularly the Madrid Protocol, as 'the most appropriate framework (...) to guarantee the protection of the environment', this does not purport any sort of appropriation regime that would be applicable to icebergs. ${ }^{83}$ Due to the moratorium on sovereignty claims in the Antarctic, one is left with somewhat of a carte blanche in this regard. The current situation as elaborated above may allude to a res nullius situation, as has also been anticipated by many authors. Another possibility, which has been advocated by a number of States, could be a 'common heritage of humankind' approach. These two possible regimes for the appropriation of icebergs for the purposes of harvesting their freshwater will be explored in the following two sections.

\section{Allocation of Property Rights for Icebergs}

Over the years, legal scholars have suggested several regimes of iceberg acquisition, effectively summarised by Lewis into three main categories. ${ }^{84}$ The first one presupposes treating icebergs as res nullius in light of ATS and UNCLOS; under the second regime icebergs were proposed to be viewed as common heritage of humankind or res communis; finally, the third approach would be based upon sovereignty claims over Antarctica and, thus, property rights. ${ }^{85}$ Although property rights by virtue of sovereignty are normally the first type of regime to come to mind, this is not feasible under the current regime governing the Antarctic. Given that all territorial claims over Antarctica remain frozen, none of the claimant States would be able to exercise property rights over icebergs. Therefore, the present paper will focus on the remaining two regimes: icebergs as res nullius and res communis.

\section{A. Res Nullius}

As discussed above, two treaties are prevalently relevant when it comes to the exploitation of Antarctic icebergs: ATS and UNCLOS. The latter divides the sea into several zones, including territorial waters, where States exercise full jurisdiction, and the high seas, open for all States. As there is no State territory Antarctica, it follows that no State Party to the ATS can claim territorial waters or an exclusive economic zone around it. ${ }^{86}$ Consequently, the waters around Antarctica constitute high seas. This is reinforced by art VI of the Antarctic Treaty on the treaty's scope ratione loci which states that nothing therein 'shall prejudice or in any way affect the rights, or the exercise of the rights, of any State under international law with regard to the high seas within that area' ${ }^{87}$ Consequently, if waters around Antarctica form part of the high seas, then Antarctic icebergs, not specifically regulated under UNCLOS and, thus, floating freely therein, may be deemed 'solidified high seas' ${ }^{88}$ and, therefore, res nullius. ${ }^{89}$ Zuccaro, on the other hand, has suggested that icebergs may fall under the doctrine of erosion, meaning

83 Recommendation XV-21 (n 56).

84 Lewis (n 9) 452.

85 ibid.

86 Lewis (n 9) 452. See also Christopher C Joyner, 'Ice-Covered Regions in International Law' (1991) 31 The International Law of the Hydrologic Cycle 213, 234-235.

87 Antarctic Treaty (n 20) art VI.

88 Joyner (n 86) 235.

89 Lewis (n 9) 452. See also Joyner (n 87) 234-235; Thomas R Lundquist, 'The Iceberg Cometh?: International Law Relating to Antarctic Iceberg Exploitation' (1977) 17 Natural Resources Journal 1, 21-26. 
that even if ice shelves fell under a State's jurisdiction while still attached to the continent, property rights would extinguish once an iceberg has separated, rendering it res nullius. ${ }^{90}$

The status of res nullius, however, does not mean unregulated access to Antarctic icebergs. It is largely accepted that due to the novelty of the activity and the scientific uncertainty of its potential implications, iceberg harvesting must prove 'consistent with general principles of high seas freedoms' in order to be compliant with UNCLOS. ${ }^{91}$ In particular, it needs to comply with the 'fundamental test of rational use', as suggested by Joyner, which would ascertain whether IFR exploitation 'can be integrated into the established law of the sea without impinging on fundamental norms' - an idea supported by other scholars in the field. ${ }^{92}$ In essence, iceberg harvesting would need to prove compatible with the freedoms of the high seas and the fundamental rules governing them, including 'international environmental legal standards meant to preserve the ocean's ecological health and to deter marine pollution'. ${ }^{93}$ Apart from this, however, icebergs having the status of res nullius would entail the freedom of any State or private entity to engage in iceberg harvesting in the high seas. From here, each State would be free to lay down the legal framework regulating the activity, including the system of rights allocation under national law. Thus, States could opt for existing legal regimes, including natural resources law or water law; conversely, a new legal act aimed explicitly at iceberg harvesting may be passed.

While the environmental regulations addressed in section 3 would be applicable to icebergs even when they are considered res nullius, it may be presumed that no entity would check whether these requirements would, in fact, be complied with and enforce them, if all States are free to appropriate icebergs drifting on the high seas. Another prevalent concern regarding icebergs being seen as res nullius is the uneven access the regime may create. While the status of res nullius would essentially ensure free access to the icebergs for any entity compliant with national laws and environmental requirements under UNCLOS and ATS, it does not guarantee equal access.

Importantly, concerns exist as to whether the lack of an international legal framework governing the acquisition of icebergs will not result in the global legal discourse being deflected by a selected group of nations. As noted by Lundquist, iceberg harvesting by one State 'must be reasonable in relation to the harvesting needs and capabilities of other countries'. ${ }^{94}$ Conflicting with this is the suggestion of Lewis - a strong proponent of the res nullius regimethat the United States must act independently in the nearest future and then steer the international legal debate such as to accommodate their own needs and reflect their national legal framework. ${ }^{95}$ These considerations largely mirror those relating to the exclusivity of the regime governing Antarctica and, in essence, raise the question of accessibility of icebergs for all Parties. Importantly, many countries that are under high risk of freshwater scarcity, such as most Middle Eastern and African States, lack the weight associated with Western powers when it comes to international legal discourse, as well as the necessary technological and financial means to harvest icebergs, ultimately indicating that the res nullius approach would hinder their equal participation in the global debate and undermine their access to IFR.

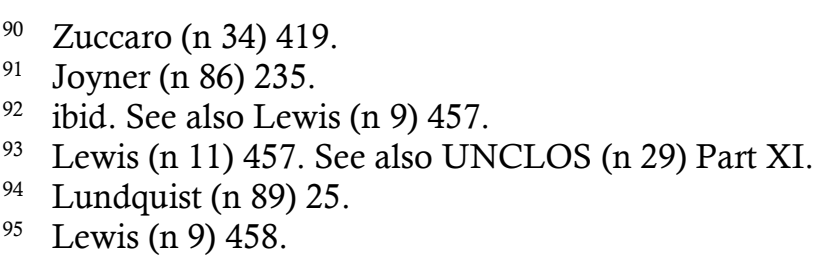


On the other hand, the chances of acceptance are significantly higher with regard to the res nullius regime than the common heritage of humankind approach. Proposed back in the late 1970s, the regime remains largely supported by legal scholars to this day. If accepted, it would guarantee free access to Antarctic icebergs instead of confining them to the authority of ATS State Parties or any particular international institution. Finally, States are likely to be in favour of the res nullius regime as it entails almost no additional burden, both on the international and national levels.

Nevertheless, given the worrying considerations connected to the inequality of access under the proposed regime and having in mind that 'uncontrolled activities relating to the exploitation of Antarctic icebergs could also have an adverse effect on the unique Antarctic environment and its dependent and associated ecosystems', ${ }^{96}$ another option to be considered is proclaiming icebergs 'common heritage of humankind', which will be discussed below.

\section{B. Common Heritage of Humankind}

The idea for a 'common heritage of humankind' approach stems from the law of the sea. More specifically, UNCLOS designated the seabed and ocean floor and subsoil thereof beyond the limits of national jurisdiction, known as 'the area', to be common heritage of humankind. ${ }^{97}$ This means that it must only be explored and exploited for the benefit of humankind as a whole, 'irrespective of the geographical location of States'. ${ }^{98}$ The explicit disregard for States' location already proves an indication as to why such a regime would be favourable for the Antarctic - it would allow universal access to its resources, irrespective of any potential sovereignty claims prone to cause conflicts in the Antarctic, and without favouring ATS members. Moreover, since an iceberg drifting on the high seas-free from any jurisdictioncannot be linked to any particular State, a system recognising this appears most equitable.

In fact, the United Nations General Assembly (UNGA), in addressing the 'Question of Antarctica', has on multiple previous occasions sought a common heritage of humankind approach. In the wake of negotiations concerning the exploitation of mineral resources in the early 1980s, prior to the adoption of the Madrid Protocol, the UNGA had stated that

any exploitation of the resources of Antarctica should ensure the maintenance of international peace and security in Antarctica, the protection of its environment, the non-appropriation and conservation of its resources and the international management and equitable sharing of the benefits of such exploitation. ${ }^{99}$

In Resolution A/RES/49/80, it reaffirmed 'that the management and use of Antarctica should be conducted (...) in the interest of (...) promoting international cooperation for the benefit of mankind as a whole'. ${ }^{100}$ The former affirmation by the UNGA illustrates the advantages that a res communis approach may have over a res nullius approach, provided it would be modelled on the regime governing the 'area' under UNCLOS. Since an authority acting on behalf of all humankind would be vested with all rights over icebergs that have calved from Antarctic ice

\footnotetext{
96 Recommendation XV-21 (n 56) preamble recital 5.

97 UNCLOS (n 27) arts 1(1) 136.

98 ibid preamble recital 6, art 140.

99 UNGA Res 41/88 B (4 December 1986) UN Doc A/RES/41/88 B, para 1.

100 ibid preamble recital 6 (emphasis added).
} 
shelves, ${ }^{101}$ immediate conflict over the icebergs would hardly ensue, allowing international peace and security to be maintained. In granting authorisations for harvesting IFR from icebergs to Parties, the authority would have to act in a non-discriminatory manner and, importantly, nevertheless afford special consideration to developing States. ${ }^{102}$ Furthermore, developing States would benefit from obligatory transfers of the necessary technology and scientific knowledge by the authority. ${ }^{103}$ This would allow for the prioritisation of access for those States most in need of drinking water, which is hardly possible under a res nullius approach, as the latter favours States with the most resources and advanced technology. Moreover, the common heritage regime under UNCLOS prescribes that States are responsible for ensuring that activities carried out by them or entities under their effective control are in compliance with all applicable rules. ${ }^{104}$ Crucially, State Parties or international organisations are liable for any damage caused by failing to adhere to these responsibilities. ${ }^{105}$ An enforcement system of this nature could facilitate the necessary compliance with the legal prerequisites for IFR exploitation under the Madrid Protocol and UNCLOS as illustrated in sections 3.2 and 3.3. above, allowing for the protection of the Antarctic environment and its dependent or associated ecosystems.

Based on the premise that Antarctica 'has no rightful sovereign owner', Joyner swiftly concluded that Antarctica should be declared res communis, rendering icebergs that have calved from it a part of the common heritage of humankind. ${ }^{106}$ However, the original ATS members agreed to have their sovereignty claims frozen - not set aside. While New Zealand was (at the time of negotiation of the Antarctic Treaty) willing to forgo its claim for the sake of a strong international governance system, this was not the case for the other Parties. ${ }^{107}$ Although more than half a century could have seen States changing their mind, it is highly unlikely that all States who had made sovereignty claims would be willing to surrender them, especially now that more is known about mineral resources resting on the continent. Similarly, even ATS consultative members without sovereignty claims would likely not be keen on abandoning their privileged say in Antarctic matters. Whereas the UN already called for a res communis approach when ATS members were discussing the exploitation of mineral resources, ${ }^{108}$ the latter States nevertheless proceeded to conclude CRAMRA in 1988 without concern for the remainder of the international community. This is the biggest shortcoming in the proposal of a common heritage of humankind appropriation regime: its implementation barely stands a chance. $^{109}$

\section{Comparative Remarks}

Overall, it is apparent that any appropriation regime governing icebergs should guarantee certain standards. According to Geon, these include certainty, considering the significant investments necessary for IFR harvesting, as outlined in section 4; fairness, in terms of

\footnotetext{
101 cf UNCLOS (n 27) art 137(2).

102 ibid art 152.

103 ibid art 144.

104 ibid art 139.

105 ibid.

106 Joyner (n 86) 236.

107 Hanessian (n 34) 470.

108 UNGA Res 41/88 B (4 December 1986) UN Doc A/RES/41/88 B, para 2.

109 See also Joyner (n 86) 237.
} 
providing access to financial and technological means to those States which most need water; efficiency, with a view to limited availability of icebergs and high costs; practicability, and adaptability for smooth implementation. ${ }^{110}$ Although States or private actors applying for authorisation to harvest icebergs could not be certain in advance whether such authorisation would be granted based on the authority's current priorities, having access to the legal framework based on which the authority would decide would provide a certain degree of legal certainty. Once authorisation is granted to an entity based on their plans, investors would have full certainty, a characteristic which cannot be guaranteed at all under a res nullius approach. Therefore, while the res nullius regime cannot ensure equal access to States who would need it the most given the dire climate conditions and severe water scarcity, the common heritage approach might constitute the most striking example for the implementation of a 'fair' regime in international law. ${ }^{111}$ The degree of efficiency would ultimately depend on the concrete implementation of the common heritage regime. Under the res nullius approach, high-level efficiency could result from competition of the various entities interested in iceberg harvesting, unless the varying levels of resources available to States would create unfair competition. Whereas the loose regulation under the res nullius approach would likely allow parties to adapt whenever needed, adaptation under the res communis approach could end up in gridlocks if members of the authority fail to come to an agreement. Conclusively, a res nullius approach is far easier to implement and would most likely be favoured by ATS consultative members. A res communis approach would, in turn, offer the environmental protection necessary for the preservation of the vulnerable Antarctic environment and its dependent or associated ecosystems. It would ensure fair and equal access to Antarctic IFR for all actors involved and, therefore, access to drinking water for those who need it most.

Ultimately, in light of legal discourse having been laid on ice since 2004, we can only hypothesise about the potential regimes and the legal implications they may have on the future development of iceberg harvesting in general. However, the following section provides an overview of the attempts to engage in large-scale Antarctic icebergs harvesting that have taken place so far, illustrating that interested parties, particularly when in dire need of drinking water, will hardly wait for States to decide on a legal framework.

\section{From Law to Practice: Iceberg Harvesting in Action A. Historical Background}

The concept of using icebergs as a source of fresh drinking water is not a novel one. In fact, inhabitants of the Arctic region such as the Inuit, have a long-standing practice of cutting and melting iceberg pieces for drinking purposes. ${ }^{112}$ However, the first large-scale idea of towing an iceberg through the ocean dates to the 1970s, when Saudi Prince Mohammad al-Faisal instructed French engineer Georges Mougin to conduct an evaluation on the possibility of bringing an Antarctic iceberg to Saudi Arabia. The findings were presented at the First International Conference on Iceberg Utilisation for Fresh Water Production, Weather Modification and Other Applications that took place in Iowa in 1977. Moreover, a pilot run was conducted, which included towing a small iceberg weighing a little over $2000 \mathrm{~kg}$ from

\footnotetext{
110 Geon (n 7) 295-96.

111 ibid 296.

112 Birkhold (n 68).
} 
Alaska. ${ }^{113}$ The research results identified a number of 'economic, political, legal, and practical obstacles'. ${ }^{114}$ Most importantly, there was no equipment advanced enough to allow tugging a massive iceberg and transporting it all the way from the Atlantic Ocean to the Saudi shore. Ultimately, the Prince discontinued the funding, thus temporarily freezing the attempts to use icebergs for freshwater purposes. However, ahead of contemporaneous technology in the 1970s, Mougin's ideas were brought back to life in 2011. Having partnered with the software company Dassault Systèmes, Mougin initiated a new venture. Using satellite data and 3D modeling, he tested the possibility of a trans-Atlantic towing of a 7 million ton iceberg wrapped in an 'insulated fabric mesh' from Newfoundland to the Canary Islands. ${ }^{115}$ According to the results, the project could be potentially realised in 141 days, while 'consuming 4,000 tons of fuel' ${ }^{116}$ Despite the considerable losses in size, the chosen iceberg 'would still weigh 4 million tons upon arrival' according to the $3 \mathrm{D}$ model. ${ }^{117}$ The project attracted the attention of an Emirati businessman, Abdulla Alsheihi, who was willing to provide the funding to deliver fresh water to the UAE in order to solve their water scarcity problem. ${ }^{118}$ A pilot run was planned for the second part of 2019; however, no information is available on the results. ${ }^{119}$ Thus, leaps made in significant technological progress have led to the gradual revival of the iceberg harvesting idea.

\section{B. Advantages of Iceberg Harvesting}

The principal advantage of iceberg harvesting is that it can potentially solve the freshwater scarcity crisis. Approximately 75\% of the world's freshwater is held in glaciers and icecaps, $90 \%$ of which are located in Antarctica. ${ }^{120}$ Antarctic glaciers produce around 140,000 icebergs annually, thus, amounting to 2,000 billion tons of ice. ${ }^{121}$ Alas, harvesting icebergs could facilitate the realisation of the human right to drinking water and the right to access to sanitation. Furthermore, accelerated by the rising temperatures, icebergs calve and melt into the ocean, causing a multitude of environmental and climatic impacts. ${ }^{122}$ Therefore, harvesting icebergs could be beneficial with a view to averting some of the threats of climate change, although this opinion is not widely supported. ${ }^{123}$ Finally, exploitation of IFR could provide a more environmentally friendly alternative to sea water desalination. This commonly used practice, which is 'expensive and energy-intensive', produces not only potable water, but also

\footnotetext{
113 Winter (n 8).

114 Lewis (n 9).

115 Smedley (n 10).

116 ibid.

117 ibid.

118 Euronews, 'Will an Emirati Businessman Succeed in Towing an Iceberg to the UAE?' Euronews (Lyon, 5 July 2019) <www.euronews.com/2019/07/05/will-an-emirati-businessman-succeed-in-towing-an-iceberg-tothe-uae $>$ accessed 26 November 2020.

119 Smedley (n 10).

120 'The World's Fresh Water Sources' (The 71 Percent) <www.the71percent.org/the-worlds-fresh-watersources/> accessed 26 November 2020.

121 Smedley (n 10).

122 See Julie Dinasquet and others (n 72); Mark J Hopwood and others (n 72); Kate Mcalpine, 'Melting Icebergs Boost Sea-Level Rise' (NewScientist, 30 April 2010) <www.newscientist.com/article/dn18841-meltingicebergs-boost-sea-level-rise/> accessed 26 November 2020.

123 Birkhold (n 68).
} 
a large amount of brine, which, when poured back into the ocean, sinks to the sea bottom, damaging marine life and depleting oxygen. ${ }^{124}$

\section{Disadvantages of Iceberg Harvesting}

Despite having a number of substantial advantages, harvesting icebergs entails several drawbacks. Most importantly, very little is known about the potential adverse environmental implications of towing icebergs across long distances. Despite Alsheihi's statement that an EIA has been conducted for the planned test project that detected 'a minimal impact to the ecosystems as well as the environment', no results have been made public. ${ }^{125}$ Consequently, the statements of interested stakeholders remain largely speculative. Nevertheless, it is impossible to deny that the impact is likely to be substantial. In particular, iceberg towing will have an immense carbon footprint. According to the estimations of marine services company Atlantic Towing, it would require 'at least 40-50 metric tons of fuel per day, per vessel' to transport a large iceberg across the ocean, releasing 5,000 metric tons of fuel into the ocean during a 100-day journey. Other organisations reaffirm the supposition that harvesting icebergs will have 'a [prohibitive] greenhouse gas footprint'. ${ }^{126}$ However, more scientific data is required before definitive conclusions can be drawn concerning this matter.

Aside from the environmental harm and despite the technological progress, towing icebergs remains an extremely expensive activity, primarily due to the lack of required facilities and installations. For instance, Nick Sloane's project of towing an iceberg to South Africa was estimated to cost over 200 million dollars. ${ }^{127}$ Transporting icebergs over longer distances to Northern Africa and the Middle East would require a substantially larger sum, which, for now, governments remain hesitant to provide. ${ }^{128}$ With present-day technologies, melted iceberg water is estimated to be five times more expensive than surface water. ${ }^{129}$

For now, it is apparent that a lot of questions regarding the prospect of iceberg harvesting remain unanswered. The above analysis illustrates the increasing potential of IFR exploitation in solving the water scarcity crisis. However, the persevering uncertainty illustrates the imperative need for further scientific cooperation and information sharing within the international community. It also highlights the necessity of reopening the international legal discourse.

\section{Conclusion}

The last time potential IFR exploitation was addressed within the ATS framework was almost thirty years ago. As demonstrated by the present paper, much has changed since then. Firstly, the severity of climate change has escalated, aggravating droughts and freshwater scarcity, and, consequently, reinforcing the necessity for alternative water sources. Secondly, we have

124 ibid.

125 Euronews (n 118).

126 Smedley (n 10).

127 Winter (n 8).

128 Thus, the South African government declined Nick Sloane's offer, inter alia, for financial reasons. Moreover, in 2011 Georges Mougin sought funding from the EU, but received a refusal. See Smedley (n 10).

129 According to the calculations conducted in Cape Town in 2018, melted iceberg water would cost 'roughly $\$ 2$ per 1,000 liters' compared to ' $\$ 0,36$ per 1,000 liters' from onshore sources, excluding the transportation costs. See ibid. 
witnessed fundamental technological improvements, giving a second life to earlier iceberg harvesting ideas, as demonstrated by the fact that trials have already been planned. Taking into consideration the lack of certainty regarding the potential environmental impacts, we can only speculate whether large-scale iceberg-towing to water scarce regions will take place in the coming years. However, an increasing number of private projects shows evidence of limited patience for States' reluctance to regulate the matter.

In the 1980s, State Parties to the ATS were eager to conclude CRAMRA before the discovery of substantial mineral deposits took place. Today, States need to follow the same approach regarding iceberg harvesting for freshwater use. Having regulations in place before the activity commences provides a degree of security and enables States to mitigate environmental damages as much as possible. Additionally, it prevents the development of customary international law potentially contrary to the objectives of the international community. Therefore, the suspended discourse needs to be revisited before it is overtaken by the practice of singular States or private entities, as the realisation of IFR exploitation becomes ever more feasible. Preservation of Antarctica for peaceful purposes should not be compromised but maintained for the common benefit of humanity and future generations. For the moment, too much remains unknown to theorise as to the form that such regulations might take. In particular, questions remain unanswered as to the legal regime that will govern the allocation of rights over the Antarctic icebergs. While viewing icebergs as res nullius will ensure a flexible framework that will require almost no additional legal decisions to be taken, it cannot guarantee fair and equal access to IFR that is possible under the res communis approach. On the other hand, the latter option, due to its complexity, might postpone reaching a consensus for an indeterminate period, which could jeopardise the attainment of an agreement before the commencement of the first large-scale iceberg harvesting projects. Nonetheless, whether the applicable regime will be negotiated within the scope of the ATS as an additional annex to the Madrid Protocol or whether a new treaty will be concluded, whether States will agree on free access to icebergs or will establish an extensive system of international cooperation, what is paramount is to ensure that the respective regime is sufficiently stringent to maintain the pristine state of the Antarctic environment. 